\title{
How Much Can the News Change a Pandemic?
}

\author{
Danielle Moore ${ }^{1}$ and Stephanie Davis" \\ ${ }^{1}$ Perry Meridian High School, Indianapolis, IN, USA \\ \#Advisor
}

\section{ABSTRACT}

Recently in 2020, Covid-19 updates have filled the news almost every day in almost every country. However, globally people are not getting the same presentation of the information. Each country has a culture and background that contributes to how they perceive the news and its production. Two countries where citizens had similar response time to Covid-19, and similar restrictions ,but still had different responses to Covid-19 are Japan and the United States of America. Part of this is attributed to the differences in societal norms and the background of these two countries. For example, "Observers have pointed out that while it is a more common sight in several East Asian societies than elsewhere in the world, mask-wearing is particularly widespread and normalized in Japan, where masks have been commonly worn outside medical or industrial settings" (Burgess, A., \& Horii, M., 2012). However, through this study it will be revealed how Japanese and American news outlets affect their citizens perception of Covid-19 and how they take the virus seriously. Japan is undoubtly a more cautious country and does do a better job at preparing it's citizens through the news.

\section{Introduction}

Recently in 2020, Covid-19 updates have filled the news almost every day in almost every country. However, globally people are not getting the same presentation of the information. Each country has a culture and background that contributes to how they perceive the news and its production. Two countries where citizens had similar response times to Covid-19, and similar restrictions, but still had different responses to Covid-19 are Japan and the United States of America. Part of this is attributed to the differences in societal norms and the background of these two countries. For example, "Observers have pointed out that while it is a more common sight in several East Asian societies than elsewhere in the world, mask-wearing is particularly widespread and normalized in Japan, where masks have been commonly worn outside medical or industrial settings" (Burgess, A., \& Horii, M., 2012).

In the United States of America, wearing a mask is not a common practice outside of medical and industrial settings. Along with that information on March 24, 2020, psychologist and former professor, Dr, Marisa Franco posted findings that "A recent poll found that 56 percent of Americans see coronavirus as a real threat - down 10 percent since last month." This shows that the coronavirus is not being seen as the threat that it is in America and that could have a correlation with how the information is being presented to Americans. Japan in contrast has as Kaori Muto an active professor in the Department of Public Policy, in The Institute of Medical Sciences at the University of Tokyo has researched." more than 80 percent of the participants implemented social distancing measures, and most Japanese citizens seem to be exhibiting some behavioral change to prevent coronavirus infections. However, this also means that about 20 percent may not be conducting sufficient prevention measures." It's interesting to think about how the news can affect counties so much that it can correlate to people's actions during a pandemic. This leads to the question of specifically how do Japan and America differ in their reporting of Covid-19 and how that affects its citizens' response to the Covid-19 pandemic? Furthermore, the citizens' view of the government does affect how they view the news reported and how they interpret the reporting. In terms of Japan, "Roughly half (53\%) believe most politicians are corrupt. And only around a third (35\%) say elected officials care what ordinary people think"(Bruce Stokes, \& 
Kat Devlin 2018). It's easy to see they have issues with their government and have some negative views of their government's decisions. However, Americans thoughts about their government are even more pessimistic with "Only $17 \%$ of Americans today say they can trust the government in Washington to do what is right "just about always" (3\%) or "most of the time" (14\%)" (pew research, 2019). The way citizens view the news and how the news gets reported correlates with their government views, especially when reporting on a pandemic where the government is a primary source of the guidelines and information. Given the information that The United States of America and Japan differ in their societal normalities, and differ in their view of the government leads to the understanding that Japan and America most likely differ in how they report Covid-19..There is also a gap in this field of research in analyzing how health communication can affect a pandemic and how much countries can differ. In order to analyze and address this gap in research, it's important to understand what good health communication looks like especially when it's a global pandemic that affects everyone. Therefore, when analyzing Japanese and the United States news articles and their health communication it's important to look at how the internet has affected health communication. It's also crucial to understand and be able to analyze health communication objectively and how health communication is perceived. The purpose of this research will lead to more people being able to analyze and understand whether or not they are receiving good health communication and the dangerous correlations that can come from receiving inadequate health communication. The research will also address the importance of health communication during a pandemic and how there needs to be some global cooperation when there is a global pandemic.

\section{Literature Review}

The basic information that Vaughan, E. with the Department of Psychology and Social Behavior, University of California, \& Tinker, T with Booz Allen Hamilton, McLean, VA. given in their 2009, research the paper provides the basis of this research. The paper stresses the importance of health communication to vulnerable populations and gives objective pandemic health communication qualities. An example of the qualities they give is, "Communications must successfully instruct, inform, and motivate appropriate self-protective behavior; update risk information; build trust in officials, and dispel rumors." This list of qualities allows the news samples from Japan and The United States of America in this study to be analyzed objectively. Another insight that Vaughan, E., \& Tinker, T. give on what good health communication should look like and do is, "Ideally; pandemic communications maximize the public's capacity to act as an effective partner by encouraging prevention, promoting containment, and fostering resilience and recovery." These objective researched qualities of good health communication not only show how much has to go into health communication, but they also create a basis for labeling the news samples and determining how well the quality of their communication about Covid-19. Vaughan, E., \& Tinker, T. have created a base set of qualities for analyzing health communication that reaches beyond this study. The qualities described in this article about health communication show that there have been people researching effective and well-received health communication and that these qualities are what made up the real received communication.

Chou WYS, Hunt YM, Beckjord EB, Moser RP, Hesse B, this group of PhDs in the medical or sociological field in 2009 study, inform that there is a concern around the new age of the internet and health communication. "Watching health-related YouTube videos was the second most reported form of social media use across all types of media and the most frequently reported form of health-related social media use $(N=709,35.4 \%)$." This shows that health is a major interest for people, and "A key finding of this study offers new and important implications for health communication in this digital age: among Internet users, social media are found to penetrate the population regardless of education, race/ethnicity, or health care access."(Chou WYS, Hunt YM, Beckjord EB, Moser RP, Hesse BW 2009). Health communication can reach broad demographics with social media. All news outlets being studied in this research have social media that they use to promote themselves and what they say. All the articles are also online new outlets that were specifically chosen because of the high view rate they get. This suggests that many people are likely to see the Covid-19 updates in the news, but that may be all they are interested in from these news outlets. People using the internet and seeing all these posts may not trust because the internet is a place that makes reaching large 
demographics easy and not everyone knows qualities of good health communication or know what to look for when trying to decide if this article is trustworthy enough to believe. The popularity of health and trying to stay healthy can clearly be abused and cause false information to be spread especially during a pandemic when health is a big concern. Therefore, it makes sense to analyze the largely viewed online news outlets when looking for the correlation between how the different health communication of America and Japan affect their citizens' response to the virus.

A Rina Miyawaki, Ai Shibata, Kaori Ishii \& Koichiro Oka (2017) in supported research in part by the National Cancer Center Research and Development Fund (26-A-31) from the Japanese Ministry of Health, Labor and Welfare s says, "that Japanese newspapers regularly published cancer-related articles throughout the year. (Kishi et al., 2008). Therefore, newspapers might easily be one of the most familiar and important sources of cancer information for the general public in Japan." This information informs that Japanese news has been a significant source of health updates for Japanese citizens, and its quality has been studied to some extent. The study in regards to the quality stated, "There is room for improvement in the reports. It would be helpful to see more effective information (Jones, Williamson, \& Hocken, 2012), such as evidence-based guidelines for prevention. Further research should consider a more indepth assessment of articles about prevention.” (Rina Miyawaki, Ai Shibata, Kaori Ishii \& Koichiro Oka 2017). This informs me that there are criticisms of Japanese health communication in the news and that guides my research to search for evidence-based guidelines and reports on prevention because the lack of those reports the quality was a criticism, and the study recommended assessing those areas of the news reports. Those qualities will also be examined in American reports to be able to make a fair comparison between the two. Overall, this sets a base for Japanese health communication and acknowledges that health communication in Japan has improvements to be made. In general, there was a lack of research in health communication that's focused on The United States so there is a huge gap in the United States health communication and how adequate it is to its citizens. This research will not completely fill that gap but will involve it in some aspects.

These studies inform of the important research in health communication and have guided where this research's focus should be and how it should be conducted. This leads this research to be American online news outlets and Japanese online news being sampled for their reporting of the first case and death domestically, first restrictions placed domestically, and first president/ Prime Minister briefing about Coid-19 and how that affected their citizens' views of Covid-19. Overall, there is a gap in understanding the effects of inadequate health communication, and this research is needed to show the correlation between inadequate health communication and the rise in health negligence.

\section{Methods}

To explain the correlation between the differences in critical Covid-19 news communication in America and Japan and how their citizens respond to the virus, the causal-comparative method will be used. The purpose of the causalcomparative is to compare and analyze comparisons and that is one of the effective ways to compare the differences in health communication in Japan and The United States and to clearly see the effects it has had. The comparison will be between the 3 most viewed American and Japanese online news outlets and 4 reports on critical covid-19 information. The most viewed American online news sources sampled are Fox News, New York Times, and Huffingtonpost according to statista.com. The most viewed Japanese online news outlets are Japan Today, Japan Times, and Nippon Hoso Kyokai (NHK) according to feedspot.com. All these news outlets have a sizeable amount of viewers meaning they can reach and influence more citizens' responses to covid-19 than smaller outlets with fewer citizens paying attention to them. The critical covid-19 reports of interest in this study are the first death (domestic), first reported cases (domestic), first restrictions placed due to covid-19 (domestic), and Prime Minister/President's covid-19 briefing. Critical reports are being looked at because they are the reports that are most likely to draw citizens' attention and have citizens read them. The reports are then coded based on the language used and the connotation it has towards regulations and the danger of the virus. The samples are also coded according to a 2009 study entitled "Effective Health Risk Communication About Pandemic Influenza for Vulnerable Populations" by Dr. Vaughan and Dr.Tinker that gives guidelines and attributes of adequate and inadequate health communication. The samples will be coded and 
given a score out of 4 based on if they meet the 4 attributes described in Dr. Vaughan and Dr. Tinker's study which are to instruct, inform, motivate, and dispel rumors that there may be. Then the news source as a whole will be given a score out of 16 based on the individual reports score out of 4 .

The information gained from the samples' coding is then compared with how the citizens respond to the first restrictions placed and how well regulations are followed in the country. This will be done by looking at if the infection rate rose while restrictions were in place to see how the people may have disregarded restrictions. This will be put in correlation with the coded samples and how many lowly scored and negative samples were gathered. If more inadequate and negative samples were gathered by the country with a higher infection rate when restrictions happened then that creates a correlation to inadequate health communication and citizens' inconsiderable response to Covid-19.

The causal-comparative method is effective in comparing and explaining correlations, and that is why it is an effective method for this research that compares the differences in how the United States of America and Japan report global news differently. This method allows for a close comparison of the articles sampled from Japan and The United States. This method's purpose is to compare and yield results that can help people think more critically when watching the news and be able to identify adequate health communication and will produce results on how influential the news is when communicating about health, and safety. Overall, the results of this method and research will demonstrate the importance of health communication and understanding how to gauge the quality of health communication being received, and how health communication is different in the United States of America and Japan due to many factors not touched on and how those differences affect the actions of citizens during a global pandemic and show a need for global corroboration, especially during a pandemic.

\section{Results}

Table 1. Japanese News Results

\begin{tabular}{|l|l|l|l|l|l|}
\hline News Outlet & $\begin{array}{l}\text { First Case } \\
\text { (domestic) } \\
\text { Article Score }\end{array}$ & $\begin{array}{l}\text { First Death } \\
\text { (domestic) } \\
\text { Article Score }\end{array}$ & $\begin{array}{l}\text { Gov } \\
\text { Briefing } \\
\text { Article Score }\end{array}$ & $\begin{array}{l}\text { Article } \\
\text { Score }\end{array}$ & Total Score \\
\hline Japan Today & $4 / 4$ & $3 / 4$ & $3 / 4$ & $2 / 4$ & $12 / 16$ \\
\hline Japan Times & $4 / 4$ & $4 / 4$ & $4 / 4$ & $4 / 4$ & $16 / 16$ \\
\hline $\begin{array}{l}\text { Nippon Hoso } \\
\text { Kyokai (NHK) }\end{array}$ & $4 / 4$ & $4 / 4$ & $4 / 4$ & $4 / 4$ & \\
\hline
\end{tabular}

The three Japan news sources and their articles did meet the qualities and expectations more than the United States. Japan Today on average in the four critical covid-19 reports analyzed met 3 out of the four qualities and was very objective and did not have any negative connotations towards restrictions in most of them. However, one did have some negative connotation in its coverage and that was the article involving restrictions. The four qualities looked for are: does the report instruct, inform, motivate, and dispel rumors that there may be. Japan Today mostly missed the motivation because the reports were very objective and had instructions on how to stay safe, but they were very minimal. Specifically, the first restrictions report from Japan Today where they failed to instruct and motivate was 
the most inadequate of Japan today's articles scoring a 2. Prime minister Shinzo Abe called for schools in Hokkaido to close and there were many people upset by this. This is fine to report but Japan Today did not comment on the fact that this is happening to keep people safe and had a very negative connotation to this regulation.

Japan Times achieved a perfect score meeting all the requirements in all their reports. They had several links to articles where they tell how to be safe during the Covid-19 pandemic within each one of their articles and they were very objective using very neutral tones but motivating people to stay safe and telling them how to stay safe. They also were very extensive in linking past articles to new ones and explaining how the virus is a crucial threat and explaining why and how it's important to stay safe during the pandemic.

Nippon Hoso Kyokai (NHK) also scored perfectly, meeting all the criteria of proper health communication. They were very health-oriented and objective in the connotation they used. In each article, there were links and hotlines to call to use if you wanted to know more about the virus and how you can stay safe. They motivated safety, informed why it's important based on the critical event that happened, and instructed safety, but calmness. Overall, this news source was very informative and objective.

Table 2. American News Results

\begin{tabular}{|c|c|c|c|c|c|}
\hline News Outlet & $\begin{array}{l}\text { First Case } \\
\text { (domestic) } \\
\text { Article Score }\end{array}$ & $\begin{array}{l}\text { First Death } \\
\text { (domestic) } \\
\text { Article Score }\end{array}$ & $\begin{array}{l}\text { Gov Briefing } \\
\text { Article Score }\end{array}$ & $\begin{array}{l}\text { Restriction } \\
\text { Article } \\
\text { Score }\end{array}$ & Total Score \\
\hline Fox news & $2 / 4$ & $2 / 4$ & $2 / 4$ & $2 / 4$ & $8 / 16$ \\
\hline New York Times & $4 / 4$ & $4 / 4$ & $4 / 4$ & $4 / 4$ & $16 / 16$ \\
\hline HuffingtonPost & $3 / 4$ & $3 / 4$ & $4 / 4$ & $4 / 4$ & $14 / 16$ \\
\hline
\end{tabular}

American news outlets' health communication did inadequately compared to Japan's health communication. Starting with Fox News failed to meet many qualities with all their articles only meeting 2 out of the 4 qualities of good health communication. Each article failed to motivate and instruct. They have the shortest reports out of all news stations because they are very objective and only have information about what has happened. They directly quote Donald Trump in several of their reports and they match his very optimistic view about the virus never providing instructions on the virus and to stay safe just having a very Laissez-faire attitude about it and do not seem motivated to stop the virus. Overall, they are objective but did not provide extensive information like the other news outlets.

New York Times articles all 4 of them meet all 4 health communication attributes. The New York Times was very objective and informative. They also have multiple resources for covid information linked in their articles and past articles to learn more directly when past events were brought up. They utilized the laissez-faire response of the United States government specifically in the briefing article. They strongly in the presidential briefing article promoted safety above all. Overall, The New York Times also had positive connotations about restrictions and staying safe and encouraging you to be clean, wear a mask, and all the important actions to take during a pandemic.

The final news outlet HuffingtonPost had their restrictions article and briefing article meet all of the communication attributes and the first domestic Covid-19 death and Covid-19 case articles meet only three of the requirements of good health communication. The ones that did not meet the requirement were lacking instruction; there was 
motivation to be safer but nothing telling how. In the articles that scored fully, they were not fully objective, they shared the belief that more should have been done to prevent the spread of Coronavirus. Overall, they were trying to be motivating that there should be more done.

Japan objectively has the more adequate news reports and better track record with covid numbers. The briefing for the United States took place on March 13th, 2020 and after that report, there was a spike in Covid-19 cases and Covid-19 cases on a 7-day average as seen in the first figure below. Every news outlet except Fox News got a 4/4 on the restriction article, Fox News got a $2 / 4$ because they failed to motivate, and instruct on what to do. This was also a briefing which means that it was focused on the government and especially in America the government and politics have been a dividing topic and were not the most motivating to stay safe during the pandemic. This leads to the understanding that because of a combination of health communication from the government and the highly viewed online news outlet that is Fox News that there is a correlation between inadequate health communication and the actions of citizens in a global pandemic. It even shows that if there is adequate health communication out there for those same citizens to see, that the inadequate health communication since it was viewed at such a high level can still correlate to those people making inconsiderate actions. In the United States, there is also the factor of the government giving poor health communication, and even with most Americans being pessimistic about the government, it is still able to correlate along with the news outlets to citizens ignoring health risk. Japan on the other hand after a state of emergency was announced on March 11th there was still a rise but the spike was slower to happen and Japan stayed at a steady rate for a longer period than The United States did this is shown in figure 2 below. The spike is also considerably less especially when comparing Japan's population density and America's average population density. There are other factors that play an impact on this like government and overall societal normalities like mask and emphasis put on health and good communication about health. Also, the amount of testing available could play a role in the slower increase; it's difficult to tell with that information not being available. However, going off this information the better health communication from Japan has had a correlation to Japanese citizens being safer and listening more to the restrictions.

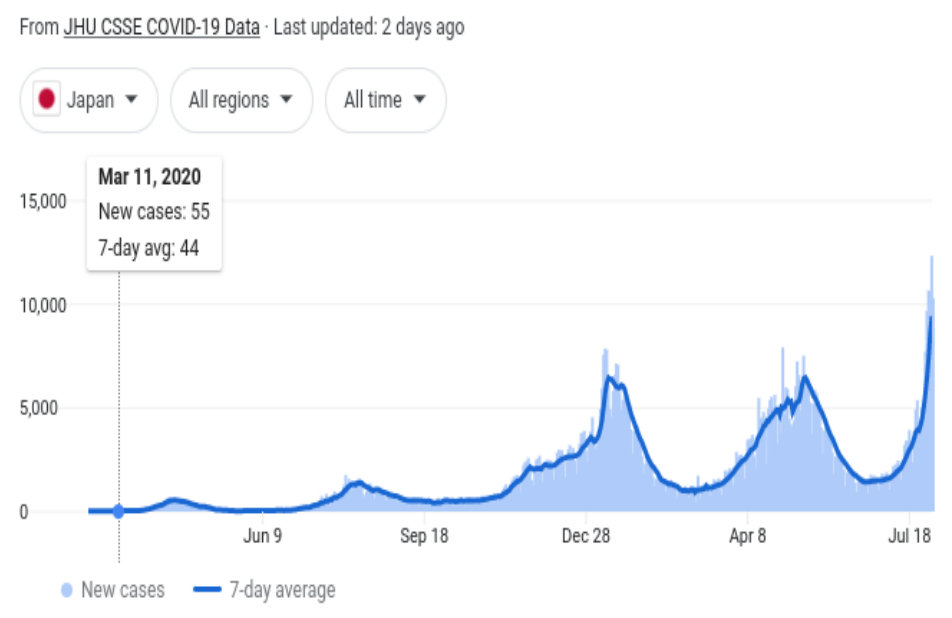

Figure 1. 


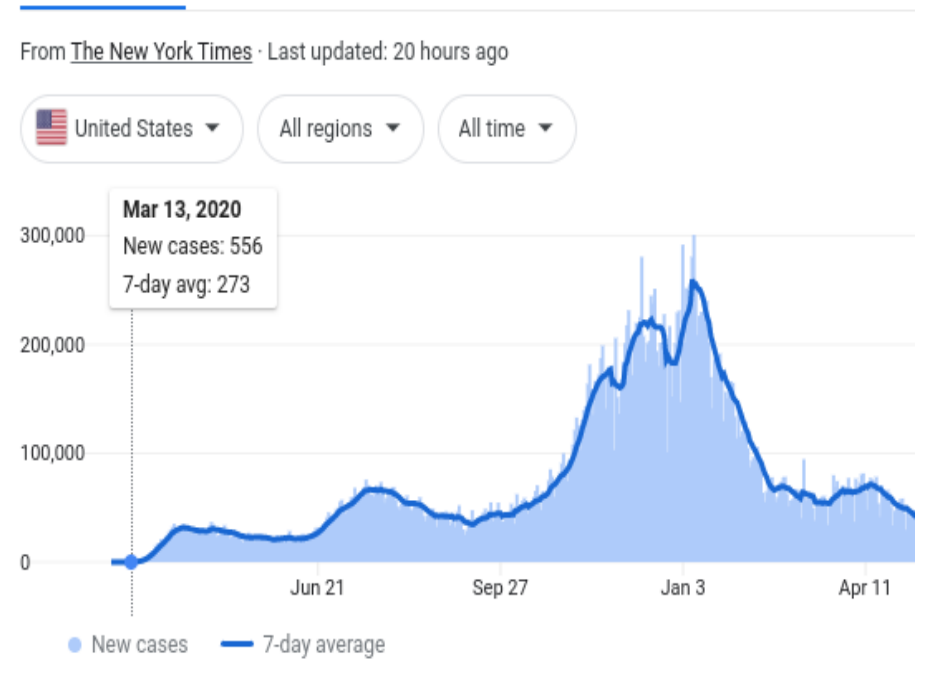

Figure 2

\section{Discussion}

These results display health communication and the importance of health and consideration of others when it comes to health has culturally been a part of Japan more than America. Also as an American, I have seen the division there is with masks and following restrictions. There is a limitation that since I am not able to see the social climate in Japan as I can in America that this may create some bias. However, with certainty, I can say that America was more divided with following restrictions and wearing masks than Japanese citizens were. This shows a need for global corporations when it comes to major health crises like these and when health communication is so critical and most people are looking for guidance through health communication given to them by the news outlets and their government.

The data gathered shows how the major differences in how health communication can be presented and the effect it can have on citizens' actions. It creates the understanding that health communication can have impacts and correlations to how citizens stay safe and react. This also shows the importance of using multiple resources when getting information about health because the media is not regulated in a way that protects from misinformation. The disconnect from country to country in receiving adequate information needs to be discussed and addressed more.

This research displays the importance of health communication and how effective it can be in keeping people safe. This research also creates an understanding that negligence to motivate and instruct citizens to stay safe can correlate with higher amounts of people disregarding restrictions and not being as safe as they could. There are several gaps that still need to be filled for example political communication on Covid-19 is an area that would also have implications on how citizens respond to the virus. Other countries with different cultures and forms of government should also be researched because there are important implications that need to be understood from those different perspectives of receiving information.

\section{Strengths/Limitations}

There are several strengths and limitations to this study. There is still a bias when perceiving the articles no matter how objective the material used to look at the articles is, as a human I am subject to bias. However, the bias in this study is not to an extreme that affects the integrity of this research. There is also a limitation to the fact that I do not 
have direct numbers of how people were reacting to the articles when posted. Also, instead of looking at Covid-19 numbers and correlating them to the article a survey could instead be given asking questions on how people feel about restrictions and if they read or watch any of the news sources used. However, a large sample would have been needed in order to conduct that type of research efficiently and with large samples comes more factors that could affect how they responded to the virus and to the survey. This in return leads me back to the original method chosen because looking at the Covid-19 cases around the time of the briefings that are close to the dates of many of the active first restrictions gives correlation to the citizens' actions and the time frame of those actions lining up with the health communication they were receiving. There was also little access to Japan and its citizens on a big enough scale that could connect to the societal climate around Covid-19 restrictions besides looking at Covid-19 cases in correlation with the date of the first briefings.

Other limitations are the scope of the question and not being able to look at the political climate and government and its effect on citizens and their reaction to the pandemic. Lastly, there are several other ways people receive news that was not addressed and the most viewed news outlets change depending on what type of media you are receiving it from for example television, radio, newspaper, and online formats all have different news outlets that are highly viewed. The average demographic of viewers is also likely to change depending on what type of media is used.

\section{Conclusion}

In the future, there should be more of a global effort at making sure people are receiving adequate health communication and more analysis on how people decide what news outlets they are going to trust and listen to. Part of this research's purpose is to inform people and create an understanding of what adequate health communication looks like, and the effects and correlation of inadequate health communication. However, there still is a missing understanding on why people have innate biases towards news outlets with clear inadequate health communication or inadequate news communication in general. The future direction of research in this field should be on how and why the news outlets that are inept at health communication reach so many and outweigh the sufficient health communication in the amount of impact it has. Figuring out the political and communication factors that come with that research may be difficult, but the results from that research will help people be able to figure out how to make sure that sufficient health communication has more of an impact than inapt communication. Overall, the new understanding that inadequate communication even when there is more adequate health communication still has a major impact needs to be researched further to figure out why and what other factors during the Covid-19 pandemic played into people listening following these news outlets inapt communication.

Acknowledgments

This Research was from my high school (Pery Merdian High School) during 2020-2021 as the Covid-19 pandemic was affecting many aspects of life, and I thank health care workers for what they have done and continue to have to do. I thank my AP Research teacher Stephanie Davis for being a great mentor in the research process, and my fellow AP Research students for peer reviews and confidence in the research process. I also thank all those who have been cited in my research. Lastly, I thank those who have done research about media's effect on people and about pandemics. Without Stephanie Davis and other peoples' previous research, I would have truly been lost with this paper so thank you.

\section{References}

Amy Mitchell, M. J. (2020, September 18). Three Months In, Many Americans See Exaggeration, Conspiracy Theories, and Partisanship in COVID-19 News. Retrieved from https://www.journalism.org/2020/06/29/three-months-in-many-americans-see-exaggeratio n-conspiracytheories-and-partisanship-in-covid-19-news/

Author, N. (2020). Japan confirms the first case of Coronavirus that has infected dozens in China. Retrieved March 
05, 2021, from

https://www.japantimes.co.jp/news/2020/01/16/national/science-health/japan-first-coron avirus-case/

Author, N. (n.d.). Japan reports FIRST COVID-19 death as more domestic CASES LOGGED. Retrieved March 05, 2021, from

https://www.japantimes.co.jp/news/2020/02/13/national/science-health/tokyo-taxi-driver-c oronavirus/

Baker, M., Bogel-burroughs, N., \& Weise, K. (2020, February 29). Washington state declares emergency Amid Coronavirus death and illnesses at nursing home. Retrieved March 05, 2021, from

https://www.nytimes.com/2020/02/29/us/coronavirus-washington-death.html?searchRes ultPosition=27

Baker, M., Crowley, M., Eavis, P., \& McNeil, D. G., Jr. (2020, February 29). Trump calls for calm on virus and expands travel restrictions. Retrieved March 05, 2021, from

https://www.nytimes.com/2020/02/29/world/coronavirus-news.html?searchResultPosition =1

Bobic, I. (2020, July 01). Republicans pushed to reopen the Economy. Now Coronavirus cases are SPIKING

AGAIN. Retrieved March 05, 2021, from

https://www.huffpost.com/entry/coronavirus-cases-trump_n_5efa07bac5b612083c50ea0 $\underline{6}$

Bremmer, I. (2020, April 09). What Japan Can Teach the World About the Pandemic. Retrieved from https://time.com/5818228/japan-coronavirus-response/

Burgess, A. and Horii, M. (2012), Risk, ritual and health responsibilisation: Japan's 'safety blanket' of surgical face mask-wearing. Sociology of Health \& Illness, 34: 1184-1198. https://doi.org/10.1111/j.14679566.2012.01466.x

Dedaj, P. (2020, March 01). Person dies FROM coronavirus in Washington STATE, first in the US, health officials say. Retrieved March 05, 2021, from

https://www.foxnews.com/us/person-dies-from-coronavirus-in-washington-state-first-in-th e-us-health-officials-say

Farber, M. (2020, January 23). First case of china-linked Coronavirus reported in US, federal officials say. Retrieved March 05, 2021, from

https://www.foxnews.com/health/first-case-coronavirus-us-seattle

Feedpost. (2021, February 27). Top 25 Japanese news websites, blogs \& influencers in 2021. Retrieved March 05 , 2021, from https://blog.feedspot.com/japanese_news_websites/

Franco, M. (2020, March 24). This Bias Explains Why People Don't Take COVID-19 Seriously. Retrieved from https://www.psychologytoday.com/us/blog/platonic-love/202003/bias-explains-why-peopl e-dont-take-covid-19seriously

Givas, N. (2020, February 29). Trump's coronavirus TRAVEL RESTRICTIONS: What you need to know.

Retrieved March 05, 2021, from

https://www.foxnews.com/us/trump-pence-coronavirus-travel-restrictions-what-to-know

Jackson, D. N., Chou, W. S., Coa, K. I., Oh, A., \& Hesse, B. (2016). Implications of social media use on health information technology engagement: Data from HINTS 4 cycle 3. Translational behavioral medicine, 6(4), $566-576$.

https://doi.org/10.1007/s13142-016-0437-1

Jun, Y. (2020, November 20). Japan confirms first death of person infected With CORONAVIRUS: Nhk WORLDJAPAN NEWS. Retrieved March 05, 2021, from https://www3.nhk.or.jp/nhkworld/en/news/backstories/875/

Kim, C., \& Park, J. (2020, February 28). Japan PM TRIGGERS uproar with call to close all schools as Hokkaido

Declares coronavirus emergency. Retrieved March 05, 2021, from https://www.reuters.com/article/us-china-healthjapan/japan-pm-triggers-uproar-with-call to-close-all-schools-as-hokkaido-declares-coronavirus-emergencyidUSKCN20M0AM

Miles, F. (2020, March 15). Trump attempts to CALM country At Wh coronavirus briefing, saying 'no need to Hoard' supplies. Retrieved March 05, 2021, from

https://www.foxnews.com/politics/trump-coronavirus-briefing-calm-supplies-groceries

Mitchell, M. J. (2020, August 21). Cable TV and Coronavirus: How Americans perceive the outbreak and view media coverage differ by main news source. Retrieved from https:/www.journalism.org/2020/04/01/cabletv-and-covid-19-how-americans-perceive-the -outbreak-and-view-media-coverage-differ-by-main-newssource/

Mitsuko, N. (2020, November 20). Japan enters "new phase" of coronavirus Outbreak: Nhk WORLD-JAPAN NEWS. Retrieved March 05, 2021, from

https://www3.nhk.or.jp/nhkworld/en/news/backstories/878/

Mitsuko, N. (2020, November 20). Japan responding to CORONAVIRUS THREAT: Nhk WORLD-JAPAN NEWS. Retrieved March 05, 2021, from 
https://www3.nhk.or.jp/nhkworld/en/news/backstories/854/

Muto, K., Yamamoto, I., Nagasu, M., Tanaka, M., \& Wada, K. (n.d.). Japanese citizens' behavioral changes and preparedness against COVID-19: An online survey during the early phase of the pandemic. Retrieved from https://journals.plos.org/plosone/article?id=10.1371/journal.pone.0234292

Papenfuss, M. (2020, February 29). Second troubling Mystery case of CORONAVIRUS reported In California.

Retrieved March 05, 2021, from

https://www.huffpost.com/entry/coronavirus-covid-19-community-spread-california-secon dcase n 5e599d24c5b6450a30be8593

Public Trust in Government: 1958-2019. (2020, May 30). Retrieved from

https://www.pewresearch.org/politics/2019/04/11/public-trust-in-government-1958-2019/

Qiu, L. (2020, March 14). Trump's false claims about his response to THE CORONAVIRUS. Retrieved March 05, 2021, from

https://www.nytimes.com/2020/03/13/us/politics/fact-check-trump-coronavirus.html?sear chResultPosition=1

Rabin, R. (2020, January 21). First patient With Wuhan Coronavirus is identified in the U.S. Retrieved March 05, 2021, from

https://www.nytimes.com/2020/01/21/health/cdc-coronavirus.html?searchResultPosition =3

Reynolds, I. (2020). Japan plays COVID-19 catch-up with Rushed state-of-emergency bill. Retrieved March 05, 2021, from

https:/www.japantimes.co.jp/news/2020/03/11/national/politics-diplomacy/japan-shinzo-a be-coronavirusemergency-bill/

Schulberg, J., \& D'Angelo, C. (2020, March 13). How trump blew the coronavirus response. Retrieved March 05, 2021, from

https://www.huffpost.com/entry/trump-coronavirus-response n 5e6ab657c5b6bd8156f4 183d

Selsky, A., \& AP. (2020, February 29). First coronavirus death In U.S. reported In Washington State. Retrieved March 05, 2021, from

https://www.huffpost.com/entry/coronavirus-first-us-death-washington_n 5e5aaa8fc5b64 50a30bf6ed5

Stokes, B., \& Devlin, K. (2020, May 31). Japanese views of their democracy. Retrieved from

https://www.pewresearch.org/global/2018/11/12/views-of-japanese-democracy/

Sugiyama, S. (2020). In dramatic broadcast, ABE asks public to FIGHT virus and announces steps to ease pain of school closures. Retrieved March 05, 2021, from

https://www.japantimes.co.jp/news/2020/02/29/national/science-health/shinzo-abe-coron avirus/

Swift, R., \& Lies, E. (2020, February 13). Japan records FIRST coronavirus death, two taxi drivers test positive. Retrieved March 05, 2021, from

https://www.reuters.com/article/us-china-health-japan-ship/japan-records-first-coronaviru s-death-two-taxi-driverstest-positive-idUSKBN20708N

Takenaka, K., \& Sieg, L. (2020, March 26). Japan, spared mass outbreak so far, now sees

'national crisis' after TOKYO SURGE. Retrieved March 05, 2021, from

https:/www.reuters.com/article/us-health-coronavirus-japan-headquarters/japan-spared mass-outbreak-so-far-nowsees-national-crisis-after-tokyo-surge-idUSKBN21D0A1

Vaughan, E., \& Tinker, T. (2009, October). Effective health risk communication about pandemic influenza for vulnerable populations. Retrieved from

https://www.ncbi.nlm.nih.gov/pmc/articles/PMC4504362/

Watson, A. (2020, September 22). Leading U.S. news websites by unique monthly VISITORS 2020. Retrieved March 05, 2021, from

https://www.statista.com/statistics/381569/leading-news-and-media-sites-usa-by-share-o $\mathrm{f}$ -

visits/\#: : text=As $\% 20$ of $\% 20$ August $\% 202020 \% 2 \mathrm{C} \% 20$ the, unique $\% 20$ visitors $\% 20$ per $\% 2$ month $\% 20$ respectively

Yamaguchi, M. (2020, January 16). Patient in Japan confirmed as having new virus from China. Retrieved March 05,2021 , from

https://apnews.com/article/3845a158612c6cc556c8cb7b91f5d078

Yamamoto Satoshi, O. (2020, November 20). Coronavirus triggers wave of EVENT cancellations: Nhk WORLDJAPAN NEWS. Retrieved March 05, 2021, from https://www3.nhk.or.jp/nhkworld/en/news/backstories/886/ 